\title{
PRELIMINARY FORAMINIFERAL SURVEY IN CHICHIRIVICHE DE LA COSTA, VARGAS, VENEZUELA
}

\author{
HUMBERTO CARVAJAL-CHITTY \& \& SANDRA NAVARRO (1) \\ Departamento de Estudios Ambientales, Laboratorio de Bioestratigrafía, \\ Universidad Simón Bolívar. Valle de Sartenejas, Caracas, Venezuela. \\ hchitty@usb.ve,sady7794@gmail.com
}

\begin{abstract}
A preliminary study of the composition and community structure of the foraminifera of Chichiriviche de La Costa (Vargas, Venezuela) is presented. A total of 105 species were found in samples from 10 to 40 meter-depth, and their abundance quantified in a carbonate prone area almost pristine in environmental conditions. The general composition varies in all the samples: at $10 \mathrm{~m}$, Miliolida dominates the assemblages but, as it gets deeper, Rotaliida takes control of the general composition. The Shannon Wiener diversity index follows species richness along the depth profile, meanwhile the FORAM index has a higher value at $20 \mathrm{~m}$ and its lowest at $40 \mathrm{~m}$. Variations in the $\mathrm{P} /(\mathrm{P}+\mathrm{B})$ ratio and high number of rare species are documented and a correspondence multivariate analysis was performed in order to visualize the general community structure. These results could set some basic information that will be useful for management programs associated with the coral reef in Chichiriviche de La Costa, which is the principal focus for diver's schools and tourism and could help the local communities to a better understanding of their ecosystem values at this location at Vargas State, Venezuela.
\end{abstract}

Keywords: Miliolida, Rotaliida, foraminiferal assemblages, FORAM index, Caribbean continental shelf.

RESUMO - Um estudo preliminar da composição e estrutura da comunidade de foraminíferos de Chichiriviche de La Costa (Vargas, Venezuela) é apresentado. Um total de 105 espécies foram encontrados em amostras de 10 a $40 \mathrm{~m}$ de profundidade e sua abundância quantificada em uma área carbonática quase intocada em termos de condições ambientais. A composição geral varia em todas as amostras: a 10 m, Miliolida domina a associação, mas à medida que se aprofunda, Rotaliida assume o controle da composição geral. O índice de diversidade de Shannon Wiener segue a riqueza de espécies ao longo do perfil de profundidade, enquanto o índice FORAM tem um valor mais alto em $20 \mathrm{~m}$ e seu mínimo em $40 \mathrm{~m}$. Variações na razão $\mathrm{P} /(\mathrm{P}+\mathrm{B})$ e número elevado de espécies raras foram documentadas, e uma análise multivariada de correspondência foi realizada a fim de visualizar a estrutura geral da comunidade. Esses resultados podem fornecer algumas informações básicas que serão úteis para programas de gestão associados ao recife de coral em Chichiriviche de La Costa, que é o principal foco para escolas de mergulho e turismo, o que pode ajudar as comunidades locais a um melhor entendimento dos valores de seus ecossistemas nesta localidade no Estado de Vargas, Venezuela.

Palavras-chave: Miliolida, Rotailiida, associação de foraminíferos, índice FORAM, plataforma continental caribenha.

\section{INTRODUCTION}

Tropical foraminiferal communities remain much of a mystery to any ecological researchers and environmental management programs. The patterns of species diversity and distributions along different depths depend on factors that have yet not been properly studied everywhere. For the Caribbean region, foraminiferal species distributions depend on salinity, temperature, nutrient availability, currents, and water quality (Murray, 2006), and on sediment transported by currents.

Within the Gulf of Mexico, to the NW of the Caribbean Sea, there is a clear separation between clastic-prone western areas impacted by outflow from the Mississippi River, and carbonate-prone eastern areas free from such impact (Poag,
2015). Hallock et al. (2003) applied the Foraminifera in Reef Assessment and Monitoring (FORAM) Index to communities associated with coral reefs off Florida in response to the U.S. Environmental Protection Agency's interest in the development of bio-indicators for coral reefs. Gischler et al. (2003) examined benthic foraminiferal assemblages along traverses across the modern isolated carbonate platforms off Belize, Central America, at water depths from $0 \mathrm{~m}$ (beach) to $40 \mathrm{~m}$ (fore reef). Cluster analyses distinguished four associations, with forereef samples characterized by abundant Amphistegina gibbosa and Asterigerina carinata, both rotaliids. High-energy, marginal-reef areas were characterized by the encrusting rotaliid Homotrema rubrum, while platform-interiors yielded common Miliolida (Archaias angulatus, Quinqueloculina sp., Triloculina sp.), 
and the rotaliid Cribroelphidium poeyanum in low-energy or deep-lagoonal regimes. Gischler \& Möller (2008) examined the benthic foraminiferal assemblages as environmental indicators on Banco Chinchorro, a carbonate platform off the Yucatan Peninsula eastern coast ( 77 species in 44 genera, 14 surface sediment samples). They found that many taxa range throughout several platform zones, such that assemblages are better environmental indicators than are individual species. Four foraminiferal assemblages were identified: (i) a Homotrema assemblage at the windward platform margin, (ii) an Archaias-Homotrema assemblage on the leeward margin and on platform interior coral patch reefs, (iii) a Quinqueloculina-Archaias-Rosalina assemblage on the western platform, and (iv) an Archaias-Quinqueloculina assemblage on the eastern platform interior. Environmental factors influencing foraminiferal distributions and diversity on Banco Chinchorro platform include wave and current exposure, and plant and algal growth, many of the taxa being epiphytal (Wilson, 2008). Sediment transport does not play a major role in Banco Chinchorro platform, few taxa being found outside their typical habitats.

Farther south, the Caribbean foraminifera in Colombia are poorly known (Fiorini, 2015), especially in the southern section. Along the Venezuelan shelf, a separation between clastic and carbonate prone areas, comparable to that in the Gulf of Mexico, might be anticipated. This southern Caribbean Sea continental shelf is to the east impacted by the hypopycnal, nutrient-rich Orinoco plume (van der Zwaan \& Jorissen, 1991; Wilson \& Hayek, 2015, 2019; Wilson et al., 2018), but not so to the west (Sellier de Civrieux, 1977a, b). The benthic foraminifera on the shelf of the clasticprone area of the SE Caribbean Sea are well documented (Drooger \& Kaasschieter, 1958; Wilson \& Hayek, 2017). The distributions of those farther west are less known (Seiglie, 1964, 1965, 1967; Sellier de Civrieux, 1968, 1977a, b; Espejo \& Velasquez, 1982), most of these papers having a taxonomic rather than an ecological bias. Sellier de Civrieux \& Ruíz (1971), however, recognized six main biofacies on the Venezuelan shelf: Florilus, Brizalina, Hanzawaia, Textularia, Quinqueloculina, and Ammonia. Carvajal-Chitty (2020) highlights the foraminiferal general richness in some locations of the western Venezuelan coastal areas, but still more research needs to be done, especially with statistics related to the physical-chemical parameters at the seafloor and along the coastline, where Ammonia is associated with nutrient-rich mangrove swamps and Quinqueloculina with more oligotrophic carbonate-prone areas. A similar pattern has been found in Puerto Rico (Culver, 1990).

The southern Caribbean shelf is oceanographically complex, being subject to upwelling of cool, nutrient-rich water at foci that are separated by areas free from upwelling (Tedesco \& Thunell, 2003a, b; Andrade \& Barton, 2005; Rueda-Roa \& Muller-Karger, 2013; Wilson \& Hayek, 2019). The pattern of sediment redistribution and upwelling in the southern Caribbean Sea changes seasonally with the arrival of the Trade Winds in the dry season and heavy rains in the hurricane season (Wilson, 2010), at which time the Inter-
Tropical Convergence Zone (ITCZ) moves north into the area (Hoffmann et al., 2014). The heavy rains influence the freshwater discharge from the Orinoco (Hu et al., 2004; Wilson \& Hayek, 2015; Wilson et al., 2018), which is the fourth largest river worldwide in terms of outflow (Hu et $a l ., 2004)$ and has the greatest range between dry and rainy season outflows of any river worldwide (van Andel, 1967). The Orinoco Plume reaches as far as north Puerto Rico (Froelich et al., 1978; López et al., 2013), and the Orinoco discharge controls the annual cycle of chlorophyll and primary productivity over that area (Müller-Karger et al., 1989). West of the plume, the western edge of which extends NW from western Trinidad, planktonic foraminifera respond to changes in upwelling associated with the migration of the ITCZ and Trade Winds fluctuations, as Tedesco \& Thunell (2003a, b) showed in their study of the monthly flux of Globigerina bulloides in the Cariaco Basin. Benthic foraminiferal populations can also be useful tools for the identification of seasonal effects (Wilson \& Dave, 2006; Wilson \& Hayek, 2015; Wilson et al., 2018) if their populations have been monitored to identify their changes after any event.

Despite the long history of intensive studies of Caribbean benthic foraminifera between 1839 and 1978 (taxonomy summarized by Culvier \& Buzas, 1982; see also Wilson, 2000 and Carvajal-Chitty, 2020), we still lack knowledge of their relationships with local ecological variables. Their importance as a powerful tool for resolving and monitoring marine environmental problems in the region (Wilson, 2000) remains underestimated. There have not yet been any studies specifically examining the distribution of benthic foraminifera at an upwelling-impacted, carbonate-prone site.

From an ecological point of view, studies in the Caribbean Sea have dealt with continental shelf and upper slope foraminifera, but field data associated with more pristine communities and their compositions are still poorly documented in the region.

Here we present a preliminary study of the foraminiferal assemblages at Chichiriviche de La Costa, Vargas State, Venezuela (Figure 1). This site is carbonate-prone, laying to the west of the Orinoco plume (see distribution map in Wilson \& Costelloe, 2011). It is, however, subject to upwelling, being at Focus F11 of Rueda-Roa \& Muller-Karger (2013). The main objective of this paper is to explore the foraminiferal community, composition, and potential structure at four different depths, setting the basis for future studies at both upwelling-impacted and upwelling-free sites along the carbonate-prone southern Caribbean continental shelf.

\section{MATERIAL AND METHODS}

Chichiriviche de la Costa is located in the western part of the Vargas State, an hour by road from the Simon Bolivar Airport in Maiquetía (Figure 1). The local community depends on fishery, but tourism is an important economic source due to the coral reef ecosystems. Four hand sediment samples ( $300 \mathrm{~g}$ ) were collected by scuba divers at $10 \mathrm{~m}, 20 \mathrm{~m}, 30 \mathrm{~m}$ and $40 \mathrm{~m}$ depth (coordinates $10^{\circ} 33^{\prime} 15^{\prime \prime} \mathrm{N}, 67^{\circ} 14^{\prime} 20^{\prime \prime} \mathrm{W}$ ) to 
be analyzed for their foraminiferal content. The samples were taken by hand, enclosed in a plastic sealed bag, refrigerated stained with 3-4 drops of rose Bengal to differentiate live or recently dead from dead organisms. Each sample was washed using a tap water tip over a 230-mesh $(63 \mu \mathrm{m})$ sieve (Murray, 2006) and dried in an oven for 24 hours at $70^{\circ} \mathrm{C}$. After drying, each sample was passed through a small sieve stack $(850 / 250 / 150 \mu \mathrm{m}$, and the pan) to pick 300 organisms per sample. All specimens were extracted by picking using a $5 \times 0$ brush and mounted in a pre-glued foraminiferal slide for identification and counting.

Each sample was exhaustively screened for foraminifera extracting both "alive" (stained) + dead organisms for identification and counting. All identification was done to the species level when possible, using the classical literature from Bermúdez (1949, 1956), Todd \& Bronnimann (1957),
Bermudez \& Seiglie (1963), Hofker (1964, 1969, 1971, 1976 , 1979, 1983), Haig (1988), Hottinger et al. (1994), Javaux \& Scott (2003), Debenay (2012), Holbourn et al. (2013), Langer et al. (2016), and Forderer \& Langer (2018). The foraminiferal database by Hesemann (2019) and WoRMS (2019) were also used as a regular check on species and updated systematics.

Data analysis by sample includes proportion by groups, diversity, and species richness (Magurran, 2004), and the FORAM index (Hallock et al., 2003), stained planktonics and benthics, $\mathrm{P} /(\mathrm{P}+\mathrm{B})$ foraminifera ratio, and relative frequency data. Finally, a correspondence analysis was performed to explore the relationships between faunal components of the samples and depths. All statistical analyses were executed by using Paleontological Statistics - PAST software (Hammer et al., 2001, version 3.x). The data collected is available by the senior author upon request.

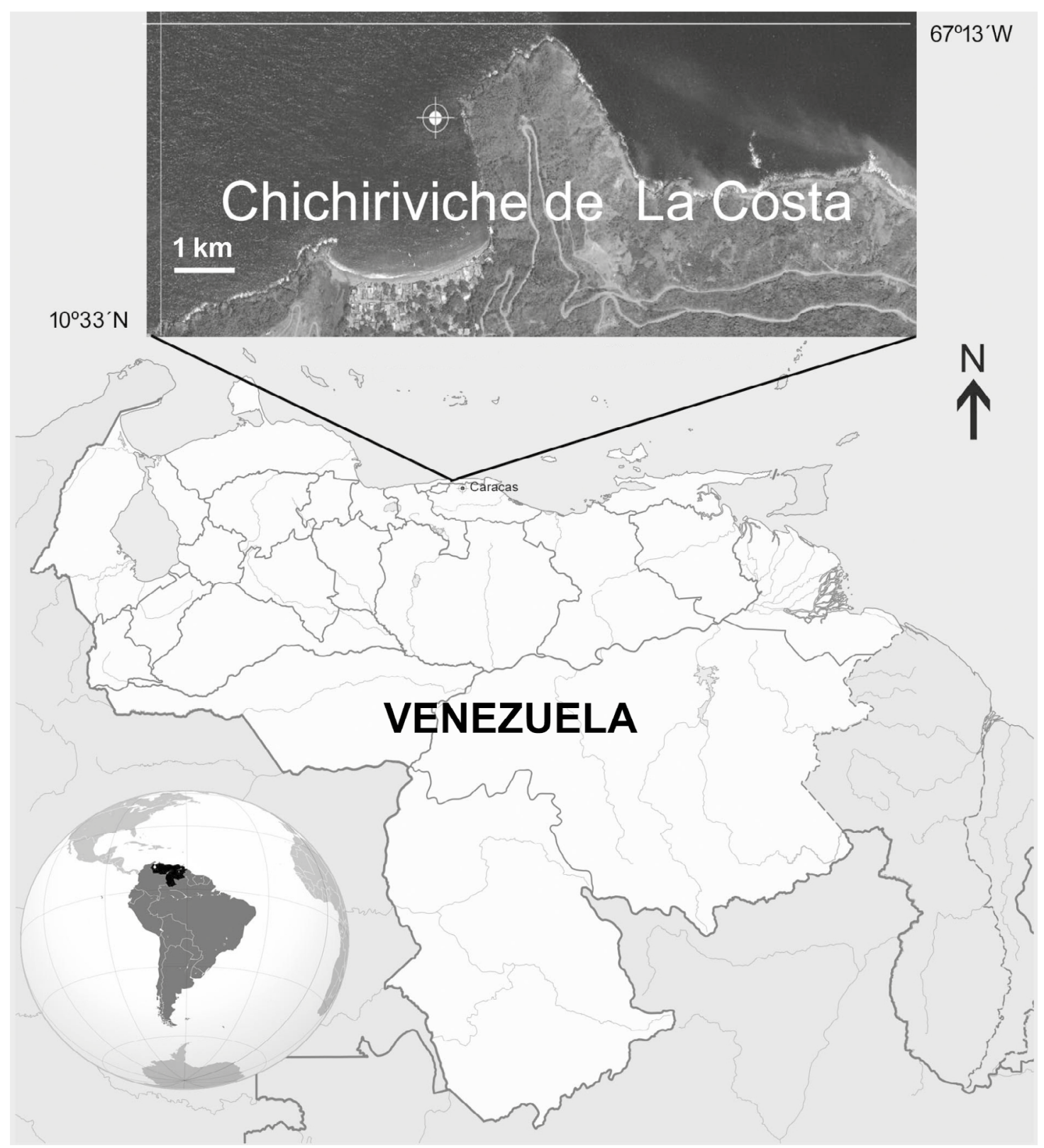

Figure 1. Location map of Chichiriviche de La Costa with sample location. 


\section{RESULTS}

All samples had similar sediment composition, being brownish/micaceous sand with large amounts of quartz grains. Sorting was poor to good. No algae material was observed in any sample. Very few coral fragments with small gastropods and other microorganisms were found in all examined samples.

A total of 105 different species (1216 specimens accounted in total) were identified and their distribution between the four different depths was quantified (Appendix 1). In general, $80 \%$ of the assemblages belong to Miliolida (44 species, $41 \%$ ) and Rotaliida (40 species, 38\%), with minor Textulariida (16 species, 15\%), Nodosarida (three species, $3 \%$ ), Spirillinida (two species, $2 \%$ ) and Carterinida (one species, 1\%) (Figure 2). The following are new records for Venezuelan coastal areas:

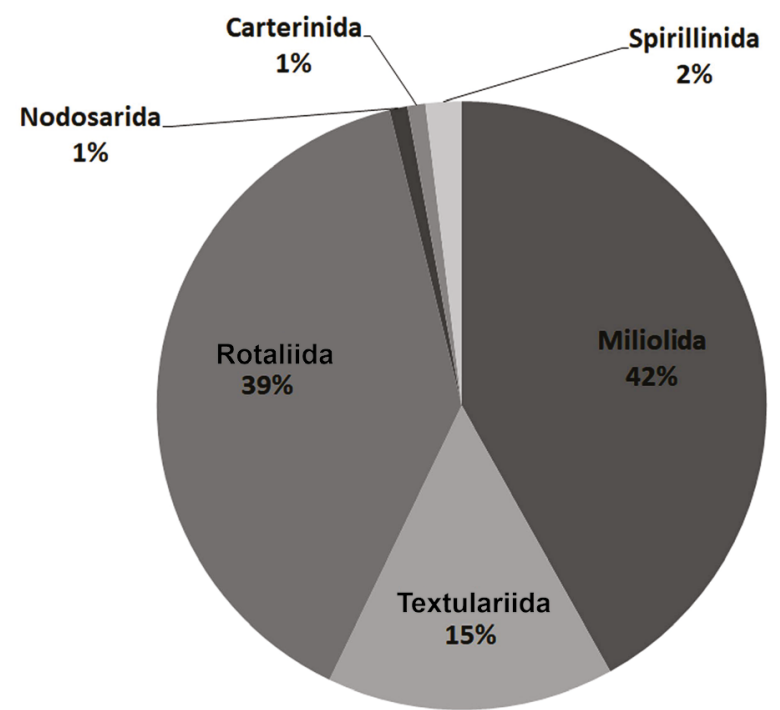

Figure 2. General foraminiferal composition, by major Order, for all samples.

Ammoglobigerina globigeriniformis (Parker \& Jones, 1865), Borelis schlumbergeri (Reichel, 1937), Cribroelphidium williamsoni (Haynes, 1973), Cymbaloporetta plana (Cushman, 1924), Dentalina vertebralis (Batsch, 1791), Dorothia scabra (Brady, 1884), Hauerina atlantica (Cushman, 1946), Hauerina pacifica (Cushman, 1917), Heterostegina depressa (d'Orbigny, 1826), Laevipeneroplis bradyi (Cushman, 1930), Miliolinella webbiana (d'Orbigny, 1839), Planispirillina inaequalis (Brady, 1879), Planorbulina distoma (Terquem, 1876), Pseudonodosinella elongata (Grzybowski, 1898), Quinqueloculina lata (Terquem, 1876), Quinqueloculina parkeri (Brady, 1881), Quinqueloculina polygona (d'Orbigny, 1839), Quinqueloculina sierralta (McCulloch, 1977), Spirorutilus carinatus (d'Orbigny, 1846), Spirosigmoilina bradyi (Collins, 1958), Subreophax aduncus (Brady, 1882), and Wiesnerella auriculata (Egger, 1893).

\section{Composition by depth}

At $10 \mathrm{~m}$, a total of 55 species were recorded $(300$ specimens total, Figure 3A), Miliolida (30 species, $55 \%$ of species richness) and Rotaliida (19 species, 34\%) dominating the sample total recovery (89\%). Textulariida (five species) and Spirillinida, (one species) made up the rest of the general composition (11\%, Appendix 1). Miliolida was represented by 160 specimens ( $53 \%$ of total recovery), the genus Quinqueloculina having 66 specimens and comprising 41\% of total Miliolida. From Rotaliida, Amphistegina lessonii was represented by 20 specimens, forming $21 \%$ of the group. These two genera, Amphistegina and Quinqueloculina, contained $29 \%$ of all species in the sample. Planktonic foraminifera are represented by 19 specimens, with Globigerinoides ruber (10 specimens) having just $6 \%$ of the total abundance. The $\mathrm{P} / \mathrm{B}$ ratio was 0.06 , reflecting total domination of benthic foraminifera over planktonic ones. Looking at "stained foraminifera" specimens, eight planktonic foraminifera were stained, in contrast to 31 benthic ones. The most abundant species found in this sample were Ammoglobigerina globigeriniformis, Amphistegina lessonii, Articulina pacifica, Hauerina atlantica, Laevipeneroplis bradyi, Quinqueoculina laevigata, Quinqueloculina polygona, Rotorbinella rosea, Spirilina vivipara, Textularia agglutinans, Treptomphalus bulloides and Triloculina trigona.

At $20 \mathrm{~m}$ (Figure 3B), 57 species were identified among 305 organisms extracted, of which 229 belonged to the Rotaliida (75\%) and 55 specimens to the Miliolida (18\%). Nineteen specimens belonged to Textulariida (6\%), and the rest to Nodosarida and Spirillinida (one specimen each one, Figure 3). Within Rotaliida, Amphistegina lessonii (140 specimens) made up $45 \%$ of the total recovery. From the Textulariida group, Textularia agglutinans and Ammoglobigerina globigeriniformis accounted for eight and seven specimens, respectively $79 \%$ of this group. Single specimens of Lenticulina sp. and Spirilina vivipara completed the sample assemblage. Planktonic foraminifers were dominated by Globigerinoides ruber, Globorotalia menardii and Trilobatus trilobus, these making up 72\% (38 specimens) of the total planktonic foraminiferal assemblage. The $\mathrm{P} / \mathrm{B}$ ratio was 0.17 , indicating a predominance of benthic individuals, but the live specimens were dominated by planktonic foraminifers, with $61 \%$ of all accounted (53 specimens, Appendix 1). Some species highlighted in this sample were $A$. globigeriniformis, A. lessonii, G. menardii, G. ruber, Pyrgo williamsoni, Siphonina tubulosa, and $T$. agglutinans.

At $30 \mathrm{~m}$ depth, 49 species were recorded in a total of 309 specimens (Figure 3C). Rotaliida comprised 26 species ( $53 \%$ of the total), followed by Miliolida, with 17 species (35\%, Figure 3C). The rest belonged to Textulariida (five species) and Carterinida (one species, Figure 5). Amphistegina lessonii, Globigerinoides ruber and Globorotalia menardii together accounted for 145 specimens, each having similar abundances. Trilobatus immaturus, Textularia agglutinans and Miliolinella spp., were common. The remaining species were rare to few (Appendix 1). Planktonic foraminifers formed 
A

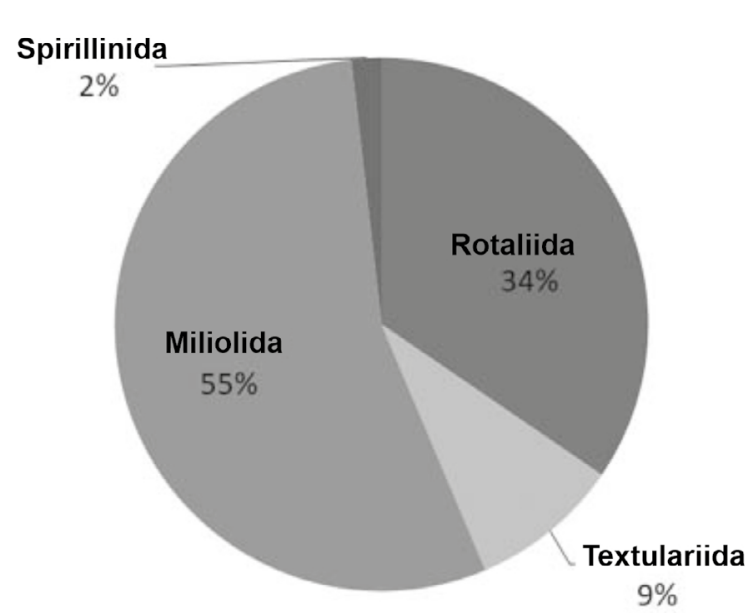

C

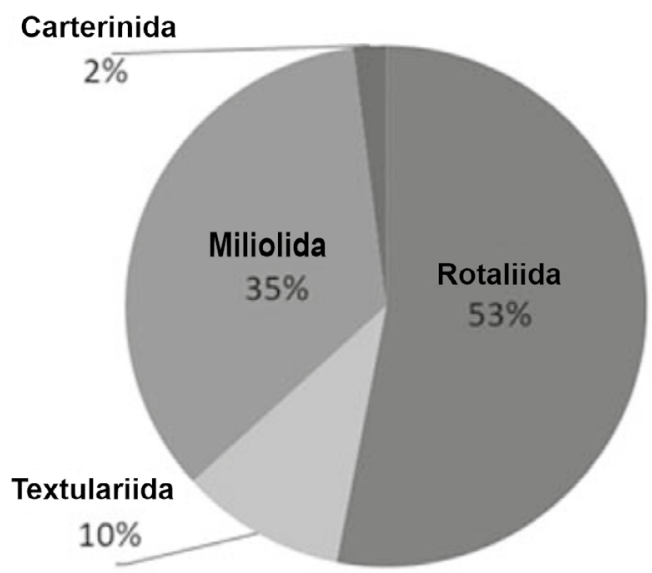

B

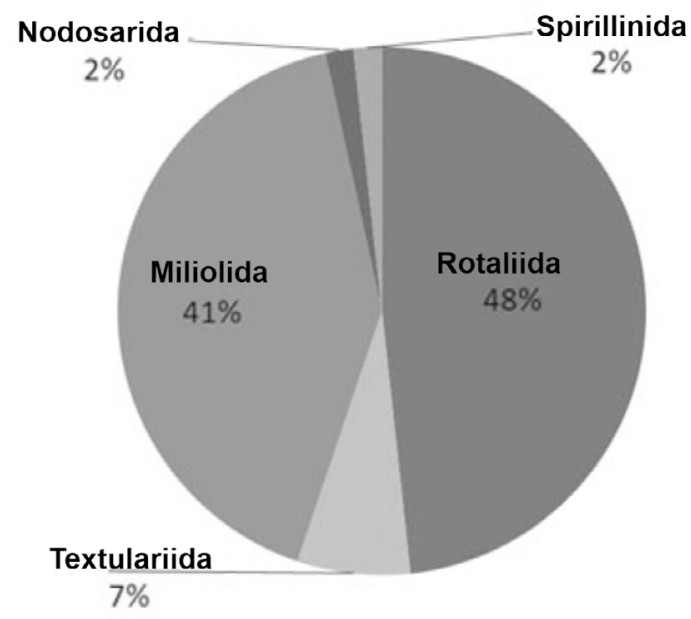

D

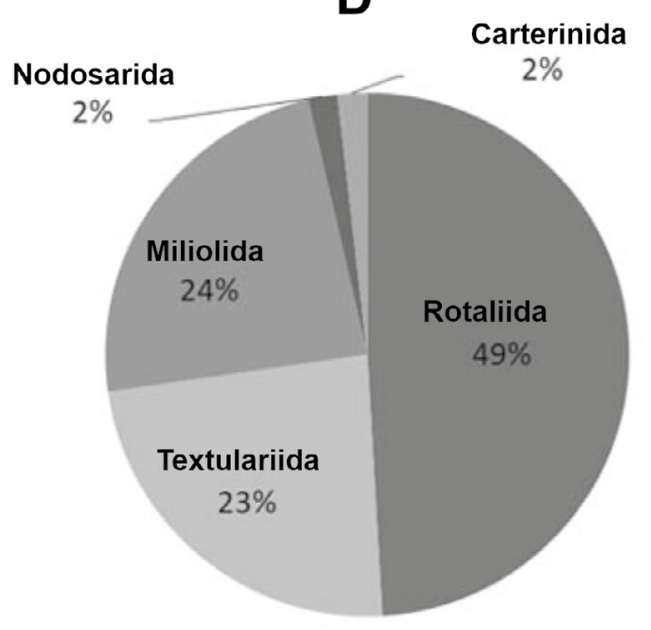

Figure 3. Foraminiferal composition by major groups for samples at $10 \mathrm{~m}, 20 \mathrm{~m}, 30 \mathrm{~m}$ and 40 meters-depth.

$47 \%$ of the total foraminifera. Regarding "stained specimens" foraminifera, planktonic specimens dominated, forming $80 \%$ of the 35 live specimens observed. Some of the more abundant taxa in this sample were A. lessonii, Eponides repandus, G. ruber, G. menardii, Neogloboquadrina dutertrei, Orbulina universa, Siphonina tubulosa, T. agglutinans, T. immaturus, T. trilobus, and Triloculina tricarinata. A new species found at this depth was recently described by Carvajal-Chitty (2019) as Haplophragmoides venezuelanus.

At $40 \mathrm{~m}, 57$ species were identified, of which $49 \%$ were Rotaliida, 24\% Miliolida and 23\% Textulariida (304 specimens, Figure 3D). The rest of the assemblage is composed by Carterinida and Nodosarida ( $2 \%$ each, Figure 3). Globorotalia menardii and Globigerinoides ruber together account for 98 specimens, with Hastigerina pelagica, Neogloboquadrina dutertrei and Orbulina universa giving 177 planktonic specimens of the total sample of 304 specimens. This means a $\mathrm{P} / \mathrm{B}$ ratio of $58 \%$, in favor of the planktonic assemblage. The same was observed for the live assemblage, with $79 \%$ of planktonic specimens. The high abundance of planktonic exemplars could be suggested as a result of currents and winds carrying surface waters loaded with these specimens towards the coastal line. The most abundant benthic taxa were Ammoglobigerina globigeriniformis, Miliolinella labiosa and Textularia agglutinans, meanwhile the most abundant planktonic taxa were G. ruber, G. menardii, H. pelagica, N. dutertrei, O. universa, Pulleniatina finalis, Trilobatus immaturus and $T$. trilobus. A new genus was found at this depth and recently described by Carvajal-Chitty (2019) as Neopateorislopsis chichirivensis.

In Figure 4 it is compared the FORAM index with the Shannon-Weiner index $\mathrm{H}$ and species richness $\mathrm{S}$ for each sample (total assemblage). The FORAM index varies from 2.89 (10 meter-depth) to a high peak of 5.77 (20 meterdepth) and a minimal value of 2.08 at $40 \mathrm{~m}$. Low values of 


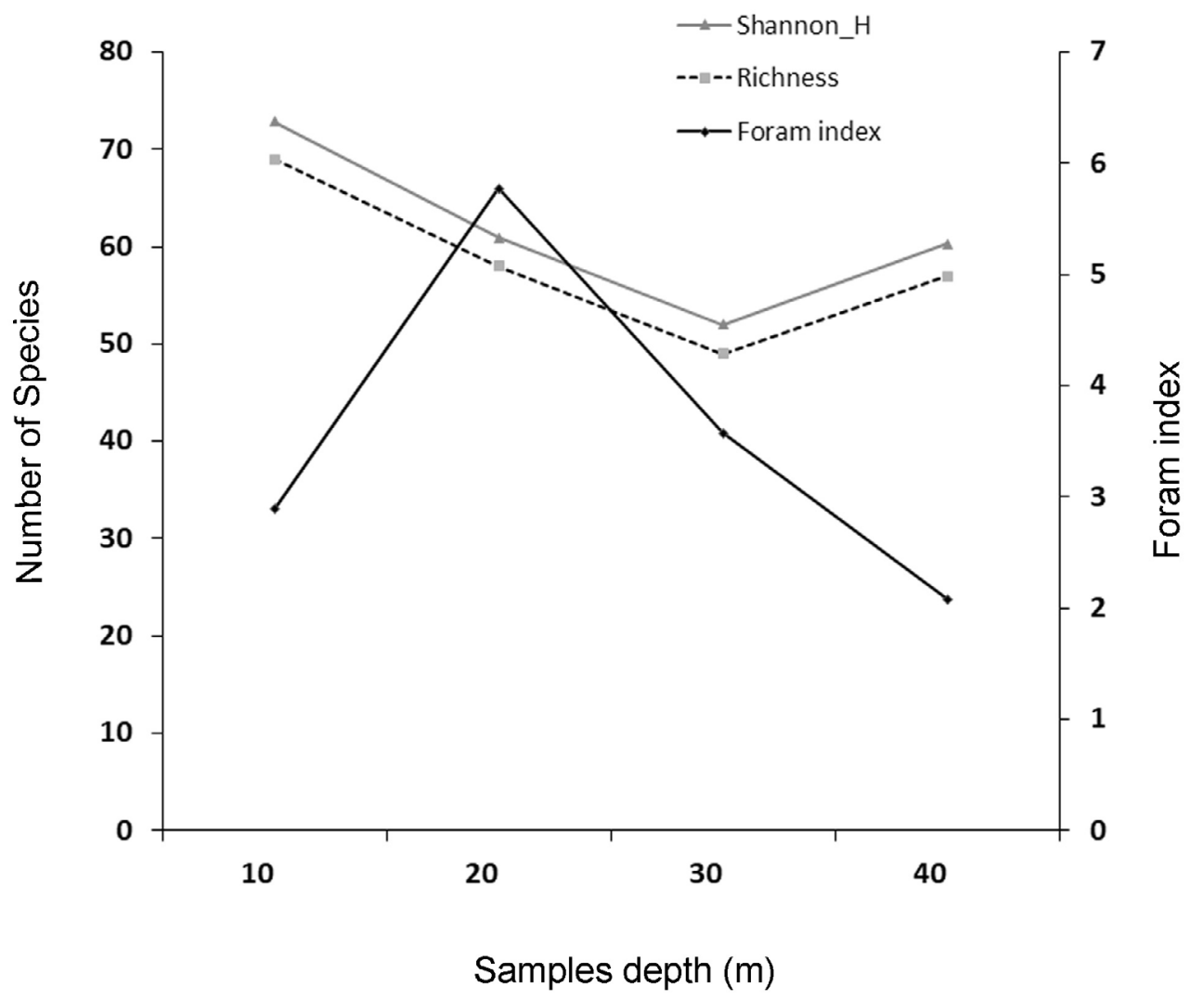

Figure 4. Variation of Shannon H index, Richness (S) and FORAM index for all samples.

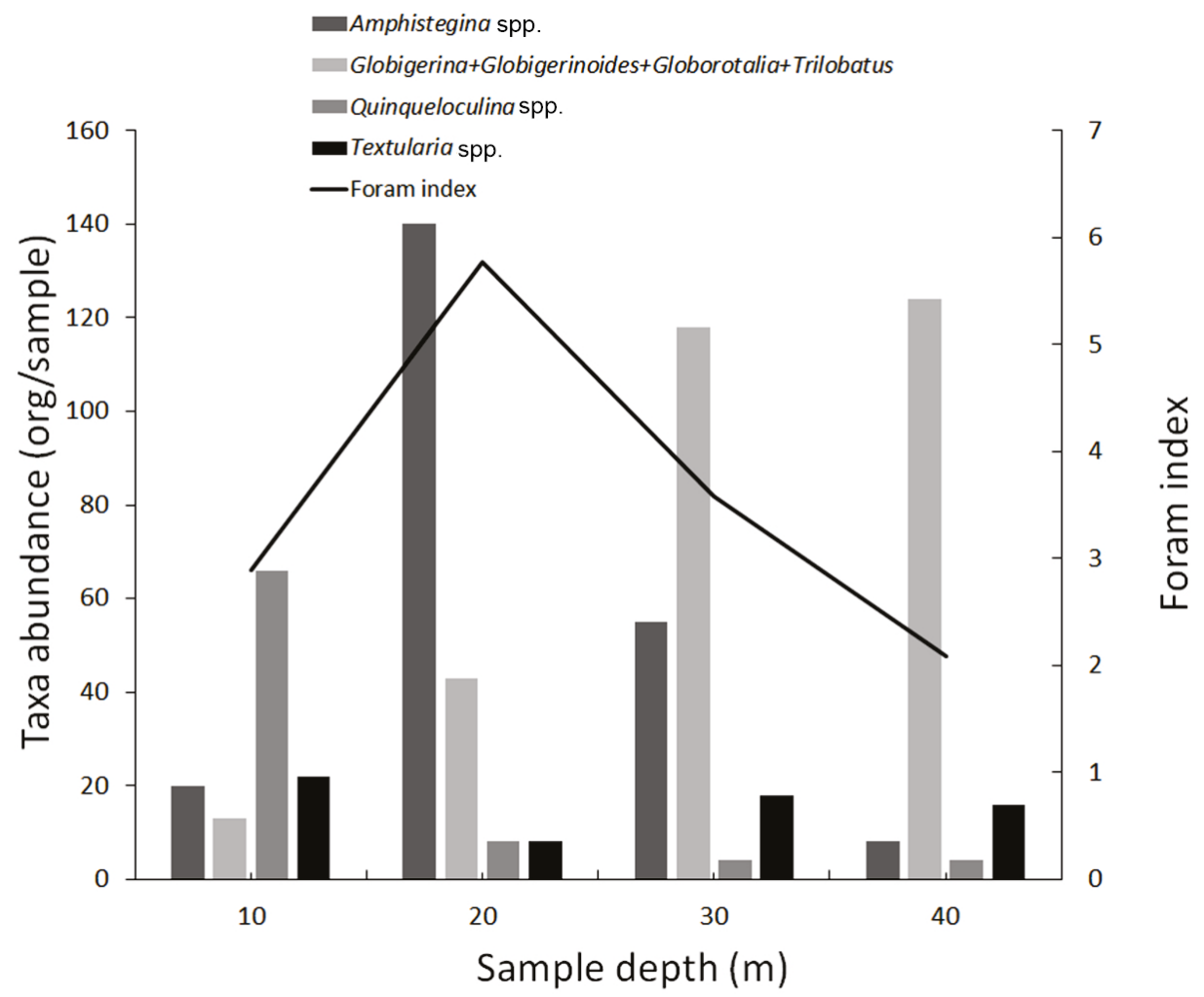

Figure 5. Abundance of selected genera and the FORAM Index along the depth profile. 
the FORAM index were associated with low abundances of symbiont bearing foraminifera like Amphistegina and Heterostegina in the samples at 10 and $40 \mathrm{~m}$, unlike samples at 20 and $30 \mathrm{~m}$, were Amphistegina (A. lessonii) has more than 55 specimens in total.

To explore how the most abundant components of each sample behave with depth, we selected four groups of foraminifera: Amphistegina, planktonic foraminifers, Quinqueloculina and Textularia (Figure 5). At $10 \mathrm{~m}$, Quinqueloculina spp. dominates together with Textularia spp., but at $20 \mathrm{~m}$ Quinqueloculina species decline while Amphistegina dominates. Planktonic foraminifers (Globigerina, Globigerinoides, Globorotalia, Trilobatus) become notable at $20 \mathrm{~m}$, attaining their maximum abundance at $40 \mathrm{~m}$. Quinqueloculina spp. and Textularia spp. are few below $30 \mathrm{~m}$. For $30 \mathrm{~m}$ and $40 \mathrm{~m}$, the FORAM index drops drastically as all symbiont bearing foraminifera quickly declined with depth (Amphistegina).

The Figure 6 shows the number of stained organisms, benthonic or planktonic, for each sample. As can be seen, the shallow sample $(10 \mathrm{~m})$ benthic foraminifera have the biggest number of alive organisms but, as it gets deeper, planktonic foraminifera increase their abundance, and the number of stained organisms in the samples rises. At $10 \mathrm{~m}$ the amount of stained benthonic species is larger than the planktonic. Even at 40 meter-depth, the amount of stained benthonic organisms is not bigger than eight, meanwhile the planktonic ones get their maximum number of stained representatives at 30 meter-depth. Stained planktonic foraminifera are four times the number of stained benthic foraminifera in samples 30 and 40 meter-depth. This is clearly demonstrated by the $\mathrm{P} /(\mathrm{P}+\mathrm{B})$ ratio, which has a step-up line from the shallowest sample to the deepest sample, favoring the planktonic component at the deepest samples, in contrast with the domination of benthonic foraminifers in the shallowest sample.

Data exploration shows many species with rare occurrences by sample. The Figure 7 illustrates the number of specimens by taxa/sample, in percentages. For every sample depth, the number of species with rare occurrences $(R$, less than five organisms of the same species recorded in a sample) is, at least $75 \%$ of total relative abundances (maximum of $89 \%$ at $20 \mathrm{~m}$ depth), meanwhile the species with more organisms in a sample (abundant, named A, more than 21 organisms recorded in a sample) have less than $4 \%$ of the total relative abundances of any sample. Few (F), common (C) and abundant (A) total relative abundances account a minimum of $11 \%$ of the total abundances (20 meter-sample) and has its higher value of $25 \%$ at 40 meter-sample. Larger number of rare species is a unique characteristic of pristine areas, like rain forest of coral reefs with minimal or non-human intervention, which allow it to support high species richness and diversity.

A correspondence analysis was performed to explore the difference between species distributions and depth (Figure 8 ). The two-dimensional chart shows that $84.24 \%$ of the variability was explained by the two first axes. As observed in Figure 9, the $10 \mathrm{~m}$ sample was quite different from those from 20,30 , and $40 \mathrm{~m}$, with more abundant species from genera Articulina, Quinqueloculina and Triloculina, that have been reported in shallow waters (Bermúdez, 1956; Hofker, 1971, 1976, 1979; Javaux \& Scott, 2003). The other samples (from bottom to top, $20 \mathrm{~m}, 30 \mathrm{~m}$ and $40 \mathrm{~m}$ ) are arrayed at the right-hand side of plot. At $20 \mathrm{~m}$, the fauna is dominated

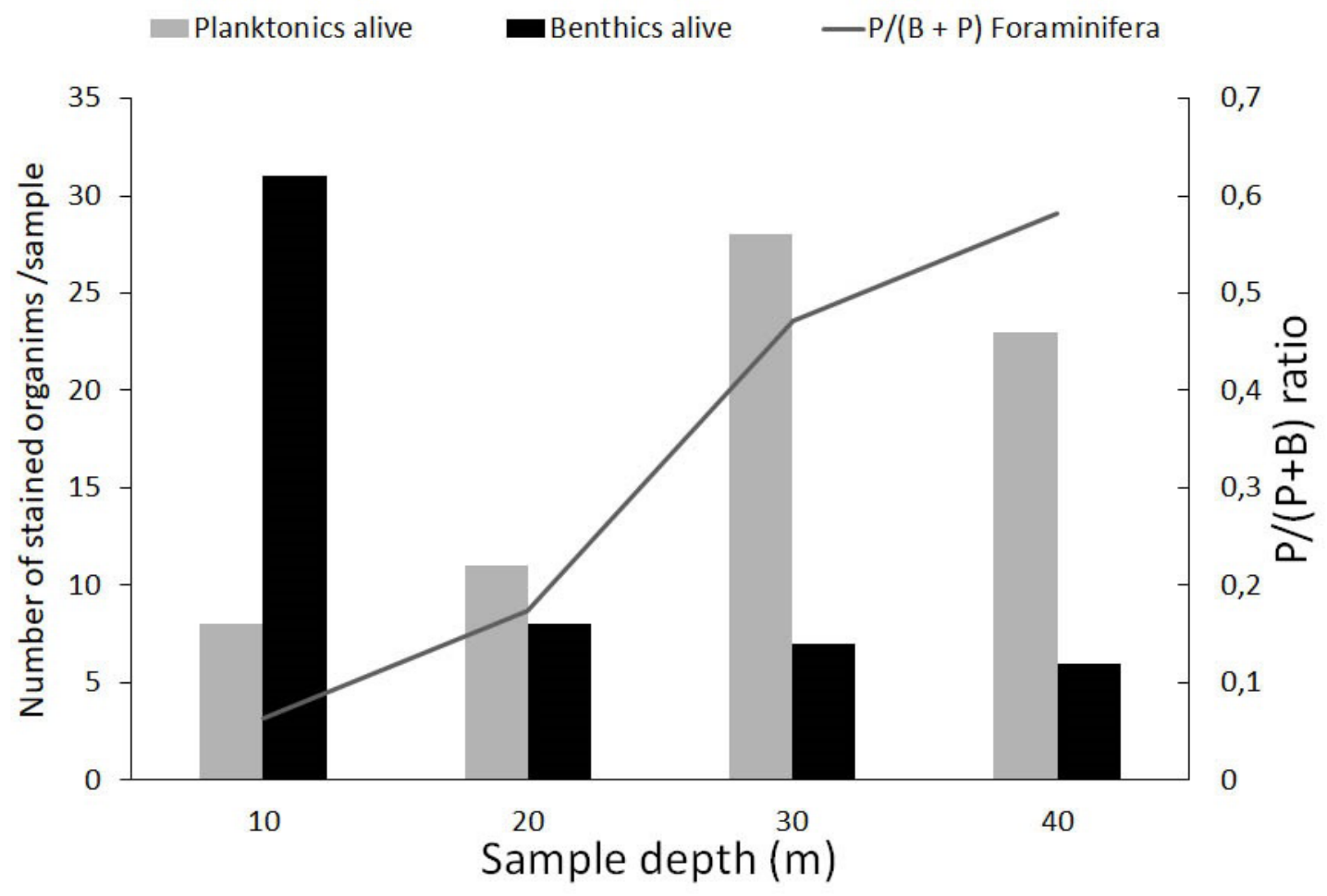

Figure 6. Number of stained organisms by benthic or planktonic and $\mathrm{P} /(\mathrm{B}+\mathrm{B})$ ratio for each sample. 


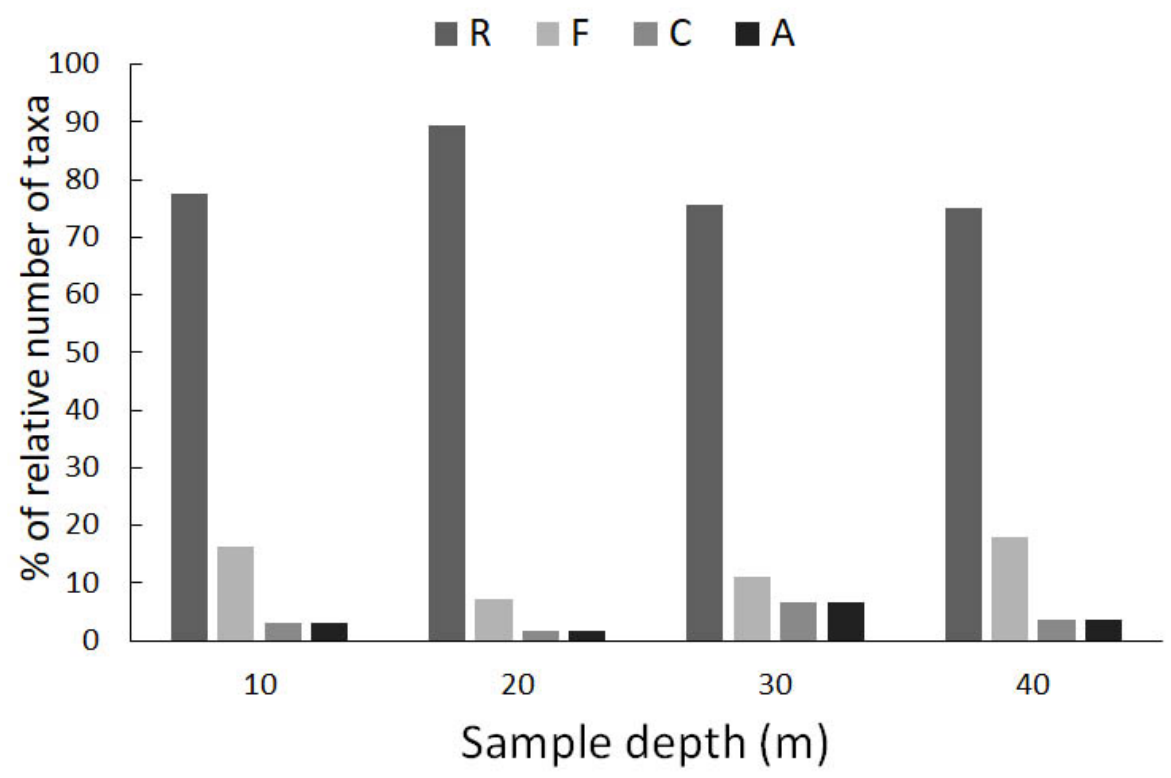

Figure 7. Relative number of organisms by taxa/sample by depth. Abbreviations: R, rare, less than five organisms by taxa/sample; F, few, between six to nine organisms by taxa/sample; $\mathbf{C}$, common, between 10-20 organisms by taxa/sample; $\mathbf{A}$, abundant, more than 21 organisms by taxa/sample.

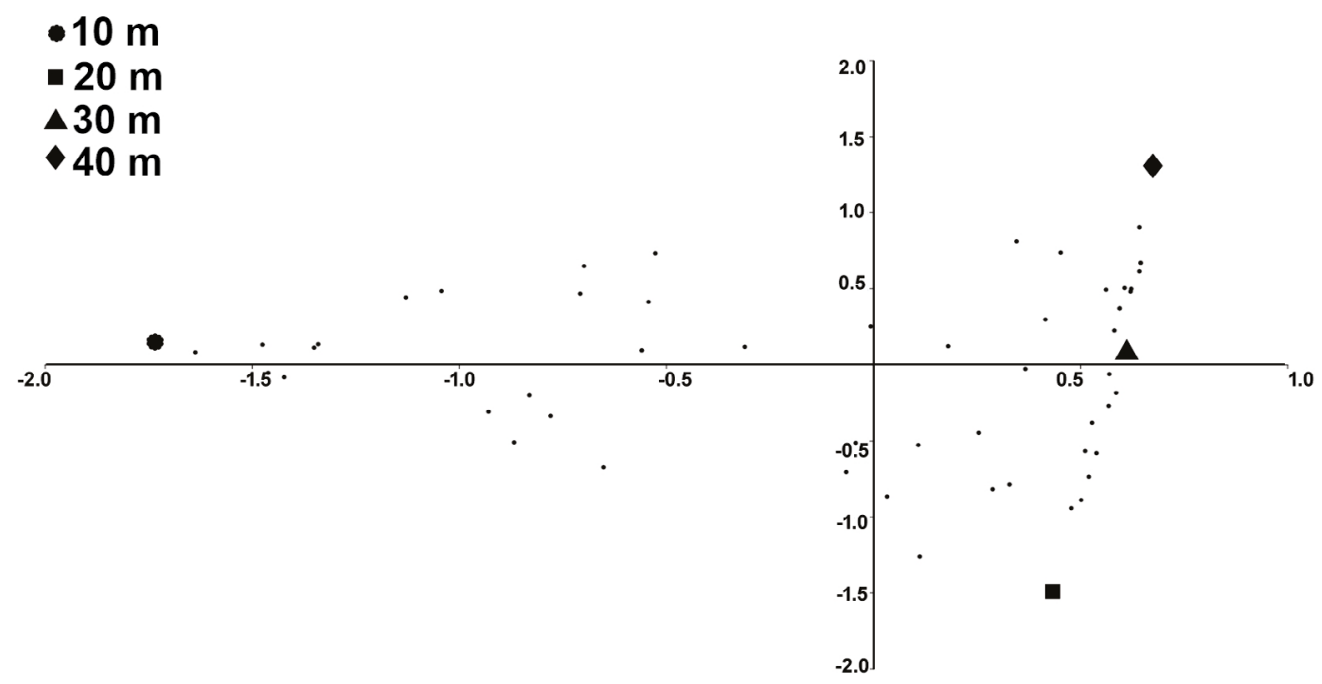

Figure 8. Correspondence analysis chart for the first two axes with $84 \%$ of variance. In the left side, the 10 meter-sample is located while samples for $20 \mathrm{~m}$, $30 \mathrm{~m}$ and 40 meter-depth are in the right side, from bottom to top right. Legend inside the chart. Black dots are species (benthic and planktonic) along the depth profile.

by Amphistegina spp., which from samples $20 \mathrm{~m}$ and $30 \mathrm{~m}$, has a maximum of $33 \%$ of the total assemblage. Samples from $30 \mathrm{~m}$ and $40 \mathrm{~m}$ have relatively similar compositions. In these samples, $30 \mathrm{~m}$ and $40 \mathrm{~m}$, the differentiation is by the planktonic foraminiferal component, which started to be the most abundant component.

\section{DISCUSSION}

The richness and diversity of species of foraminifers from Chichiriviche de La Costa vary among depths, as predicted for the Caribbean Sea by Buzas \& Culver (1991). In general, variations in richness among samples is evident with the change in composition with depth, which is correlated with species requirements with depth (Armstrong \& Brasier, 2005; Murray, 2006). The 107 species recovered is a high number when compared with other Venezuelan locations like Los Roques (53 species by Bermúdez, 1956), Margarita (93 species by Miró, 1965), and low for extensive studies like Bermudez \& Seiglie (1963), with 205 species for Cariaco Basin. The pattern of genera distribution and the depth profiles is, in general terms, very similar to the modern isolated 
carbonate platforms off Belize, Central America by Gischler et al. (2003) and Banco Chinchorro, a carbonate platform off the Yucatan Peninsula eastern coast (Gischler \& Möller, 2008), at assemblages level.

The miliolids slowly declined with depth (from 55\% to $24 \%$ of sample total abundance). This agrees with general models of foraminiferal distributions (e.g. Halfar \& Ingle, 2003; Armstrong \& Brasier, 2005) in which miliolids dominated the foraminiferal composition in the inner part of the inner neritic marine setting, while at proximal middle neritic depths the Rotaliida begin to dominate over other foraminiferal groups. The presence of rare components, not only from the miliolids and rotaliids, but from other groups like Lagenida, Carterinida and Spirillinida, also agrees with Buzas \& Culver's (1991) statement about endemism and rare species observed in the Caribbean. In all samples from Chichiriviche de La Costa, the basic foraminiferal composition has many species. Rare species vary from 3 $(30 \mathrm{~m})$ to 18 species $(10 \mathrm{~m})$, which indicates high variability between samples.

The FORAM Index increases $100 \%$ from $10 \mathrm{~m}$ to $20 \mathrm{~m}$ (from 2.89 to 5.77), it remains high at 30 meter-sample (3.57), decreasing quickly at $40 \mathrm{~m}(2.08)$. This pattern agrees with the Florida Keys pattern for similar depths (Hallock et al., 2003) and supports, indirectly, the high diversity and richness in the coral reef on this location. Hetzinger et al. (2016) highlight changes in coral extension rate in Chichiriviche de La Costa, associated with El Niño. Recently, López-Hernández et al. (2019) classify the coral communities at Chichiriviche de La Costa as fair, according with their evaluations for coral communities below $20 \mathrm{~m}$ depth. Our preliminary results from the FORAM index could suggest that the coral community at $20 \mathrm{~m}$ could have optimal water conditions for growth and development, but the conditions are not the same for the community at $10 \mathrm{~m}$. Regarding $30 \mathrm{~m}$ and $40 \mathrm{~m}$ depth samples, conditions are much better for planktonic foraminifera, but not necessarily for the coral community. The correspondence analysis shows changes along the depth gradient that follow, independently, what the FORAM index and the richness pattern have shown. This could help design the next step for a more detailed survey in this location.

Stained foraminifera show the classic behavior described to Armstrong \& Brasier (2005), Murray (2006) and Seears et al. (2012) with a natural increase in planktonics when the water column gets deeper than $20 \mathrm{~m}$. Rare species per samples have remarkably high number along all locations. This is particularly important because it highlights the high diversity in tropical foraminifera communities, especially in the Southern Caribbean, which could be an index of almost pristine marine environment or marine with minimal perturbations by human activities.

Monitoring and surveying foraminiferal composition along a depth gradient within coral reef areas could yield more data about the environmental quality from an independent perspective. This is something that will need to be tested in the future with more detailed sampling and replication in order to bring more data for future changes in the neotropical reef communities. Still much work is needed in Venezuelan coastal areas.

In conclusion, the data presented here illustrated the variability of the foraminiferal community in Chichiriviche de La Costa and could be used as an indicator of marine pristine environment (related to the high number of rare species) and set a baseline data for future work on annual variation and its relationship with physical-chemical and sedimentological variables that could have effects on the foraminiferal community.

\section{ACKNOWLEDGEMENTS}

We would like to express ours acknowledges to C.G.M. Zumbo for providing the samples, B. Wilson for his suggestions and corrections to this manuscript. Special thanks to A.M. Ribeiro, M. Arai and an anonymous review for the comments and recommendations. I would like to dedicate this article to the memory of Max Furrer, Pedro Roa and Evelyn Zoppy de Roa.

\section{REFERENCES}

Andrade, C.A. \& Barton, E.D. 2005. The Guajira upwelling system. Continental Shelf Research, 25:1003-1022. doi:10.1016/j. csr.2004.12.012

Armstrong, H.A. \& Brasier, M.D. 2005. Microfossils. 2nd edition. Oxford, Blackwell Publishing, 304 p.

Bermúdez, P.J. 1949. Tertiary smaller foraminifera of the Dominican Republic. Cushman Laboratory for Foraminiferal Research, 25:1-322.

Bermúdez, P.J. 1956. Foraminíferos recientes de Los Roques, Venezuela. In: El Archipiélago de Los Roques y La Orchila, Sociedad de Ciencias Naturales La Salle, p. 173-183.

Bermúdez, P.J. \& Seiglie, G. 1963. Estudio sistemático de los foraminiferos foraminíferos del Golfo de Cariaco. Boletín del Instituto Oceanografico Oceanográfico de la Universidad de Oriente, 2:1-267.

Buzas, M.A. \& Culver, S.J. 1991. Species diversity and dispersal of benthic foraminifera. BioScience, 41:483-489.

Carvajal-Chitty, H. 2019. Two new foraminiferal taxa from coastal Venezuela: the newmiliolid genus Neopateorislopsis n. gen., and the new lituolid species Haplophragmoides venezuelanus $\mathrm{n}$. sp. Micropaleontology, 65:545-550.

Carvajal-Chitty, H. 2020. Richness in recent foraminifera from different locations along Venezuelan coastal ecosytems. Micropalentology, 66:143-150.

Culver, S.J. 1990. Benthic foraminifera of Puerto Rican mangrovelagoon systems: potential for paleoenvironmetnal interpretations. Palaios, 5:34-51. doi:10.2307/3514995

Culvier, S.J. \& Buzas, M.A. 1982. Distribution of Recent benthic foraminifera in the Caribbean area. Smithsonian Contributions to the Marine Sciences, 1-382. doi:10.5479/si.01960768.14.1

Debenay, J.-P. 2012. A guide to 1000 foraminifera from Southwestern Pacific, New Caledonia. Marseille, IRD; Paris, Muséum national d'Histoire naturelle, $384 \mathrm{p}$.

Drooger, C.W. \& Kaasschieter, J.P. 1958. Foraminifera of the Orinoco-Trinidad-Paria Shelf. Report of the Orinoco Shelf Expedition. Vol. 4. Verhandlungen Koninklijk Nederland Akademie Wetenschappelijke, 108 p. 
Espejo, R.A. \& Velasquez, P.I.G. 1982. Aspectos generales sobre asociaciones de foraminíferos bentónicos del Golfo de Venezuela y talud continental adyacente. GEOLOGICAL CONFERENCE OF THE CARIBBEAN, 9, 1982. Transactions, Santa Domingo.

Fiorini, F. 2015. Recent benthic foraminifera from the Caribbean continental slope and shelf off west of Colombia. Journal of South American Earth Sciences, 60:117-128. doi:10.1016/j. jsames.2015.03.003

Forderer, M. \& Langer, M.R. 2018. Atlas of benthic foraminifera from coral reefs of the Raja Ampat Archipelago (Irian Jaya, Indonesia). Micropaleontology, 64:1-170.

Froelich Jr., P.N.; Atwood, D.K. \& Giese, G.S. 1978. Influence of the Amazon River discharge on the surface salinity and dissolved silicate concentrations in the Caribbean Sea. Deep Sea Research, 25:735-744. doi:10.1016/0146-6291(78)90627-6

Gischler, E.; Hauser, I.; Heinrich, K. \&. Scheitel, U. 2003. Characterization of depositional environments in isolated carbonate platforms based on benthic foraminifera, Belize, Central America. Palaios, 18:236-255. doi:10.1669/08831351(2003)018<0236: CODEII>2.0.CO;2

Gischler, E. \& Möller, A. 2008. Modern benthic foraminifera on Banco Chinchorro, Quintana Roo, México. Facies, 55:27-35. doi:10.1007/s10347-008-0162-4

Haig, D.W. 1988. Miliolid foraminifera from the inner neritic sand and mud facies of the Papuan Lagoon, New Guinea. Journal of Foraminiferal Research, 18:203-236.

Halfar, J. \& Ingle Jr., J.C. 2003. Modern warm-temperature and subtropical shallow water benthic foraminifera of the southern Gulf of California, Mexico. Journal of Foraminiferal Research, 33:309-329. doi:10.2113/0330309

Hallock, P.; Lidz, B.H.; Cockey-Burkhard, E.M. \& Donnelly K.B. 2003. Foraminifera as bioindicators in coral reef assessment and monitoring: the FORAM Index. Environmental Monitoring and Assessment, 81:221-238. doi:10.1023/A:1021337310386

Hammer, Ø.; Harper, D.A.T. \& Ryan, P.D. 2001. PAST: Paleontological statistics software package for education and data analysis. Palaeontologia Electronica, 4:1-9.

Hesemann, M. 2019. The Foraminifera.eu Project. Available at http:// Foraminifera.eu; accessed on 09/17/2018.

Hetzinger, S.; Pfeiffer, M.; Dullo, W.-Chr.; Zinke, J. \& GarbeSchonberg, D. 2016. A change in coral extension rates and stable isotopes after El Niño induced coral bleaching and regional stress events. Scientific Reports, 6:32879. doi:10.1038/srep32879

Hoffmann, J.; Bahr, A.; Voigt, S.; Schönfeld, J.; Nürnberg, D. \& Rethemeyer, J. 2014. Disentangling abrupt deglacial hydrological changes in northern South America: insolation versus oceanic forcing. Geology, 42:579-582. doi:10.1130/G35562.1

Hofker, J. 1964. Foraminifera from the tidal zone in the Netherlands Antilles and other West Indian Islands. Studies on the Fauna of Curaçao and other Caribbean Islands, 2:1-119.

Hofker, J. 1969. Recent foraminifera from Barbados. Studies on the Fauna of Curaçao and other Caribbean Islands, 31:1-158.

Hofker, J. 1971. Foraminifera of Piscadera Bay, Curazao. Studies on the Fauna of Curaçao and other Caribbean Islands, 35:1-62.

Hofker, J. 1976. Further studies on Caribbean Foraminifera. Studies on the Fauna of Curaçao and other Caribbean Islands, 49:1-256.

Hofker, J. 1979. Rare and remarkable Foraminifera of the Caribbean Sea. Studies on the Fauna of Curaçao and other Caribbean Islands, 5:1-43.

Hofker, J. 1983. Zoological exploration of the continental shelf of Surinam: the foraminifera of the shelf of Surinam and the Guyanas. ZoologischeVerhandelingen, 201:1-70.
Holbourn, A.; Henderson, A.S. \& Macleod, N. 2013. Atlas of benthic foraminifera. Chichester, Wiley-Blackwell, $651 \mathrm{p}$.

Hottinger, L.; Halicz, E. \& Reiss, Z. 1994. Recent Foraminifera from the Gulf of Aqaba, Red Sea. Academia Scientiarum et Artium Slovenica, Classis IV: Historia Naturalis, 33; Paleontoloski Institut Ivana Rakovca, 3, 179 p.

Hu, C.; Montgomery, E.T.; Schmitt, R.W. \& Muller-Karger, F.E. 2004. The dispersal of the Amazon and Orinoco River water in the tropical Atlantic and Caribbean Sea: observation from space and S-PALACE floats. Deep Sea Research II, 51:1151-1171. doi:10.1016/j.dsr2.2004.04.001

Javaux, E.J. \& Scott, D.B. 2003. Illustration of modern benthic foraminifera from Bermuda and remarks on distribution in other subtropical/tropical areas. Palaeontologia Electronica, 6:1-29.

Langer, M.R.; Mouanga, G.H. \&. Fajemila, O.T. 2016. Shallow-water nearshore benthic foraminifera from Gabon. Micropaleontology, 62:69-80.

López, R.; López, J.M; Morell, J.; Corredor, J.E.; \& Del Castillo, C.E. 2013. Influence of the Orinoco River on the primary production of eastern Caribbean surface water. Journal of Goephysical Research: Oceans, 118:4617-432. doi:10.1016/0146-6291(78)90627-6

López-Hernández, A.M.; Montilla, L.M.; Verde, A.; Agudo-Adriani, E.; Rivera, A.; Miyazawa, E.; Mariño, G.; Ascanio, A. \& Cróquer, A. 2019. Venezuelan coral reefs: a health assessment using the Reef Health Index with complementary variables. MEETING OF THE ASSOCIATION OF MARINE LABORATORIES OF THE CARIBBEAN, 39, 2019. doi:10.5281/zenodo. 3235468

Magurran, A.E. 2004. Measuring biological diversity. Malden, Blackwell Science Ltd, 215 p.

Miró, M.D. de. 1965. Comparación de la fauna de foraminiferos de los sedimentos de la Fosa de Cariaco con la del área oceánica adyacente. Memorias de la Sociedad de Ciencias Naturales la Salle, 25:225-236.

Müller-Karger, F.E.; McClain, C.R.; Fisher, T.R.; Esaias, W.E. \& Varela, R. 1989. Pigment distribution in the Caribbean sea: observations from space. Progress in Oceanography, 23:23-64. doi:10.1016/0079-6611(89)90024-4

Murray, J. 2006. Ecology and Applications of Benthic Foraminifera. Cambridge, Cambridge University Press, $x i+426 \mathrm{p}$.

Poag, C.W. 2015. Benthic foraminifera of the Gulf of Mexico: distribution, ecology, paleoecology. College Station, Texas A\&M University Press, $256 \mathrm{p}$.

Rueda-Roa, D.T. \& Muller-Karger, F.E. 2013. The southern Caribbean upwelling system: sea surface temperature, wind forcing and chlorophyll concentration patterns. Deep Sea Research I, 78:102-114. doi:10.1016/j.dsr.2013.04.008

Seears, H.A.; Darling, K.F. \& Wade, C.M. 2012. Ecological partitioning and diversity in tropical planktonic foraminifera. BMC Evolutionary Biology, 12:54. doi:10.1186/1471-214812-54

Seiglie, G.A. 1964. New and rare foraminifers from Los Testigos reefs, Venezuela. Caribbean Journal of Science, 4:497-512.

Seiglie, G.A. 1965. Some observations on Recent foraminifers from Venezuela: Part 1. Contributions of the Cushman Foundation for Foraminifera Research, 16:70-73.

Seiglie, G.A. 1967. Systematics of the foraminifers from Araya-Los Testigos shelf and upper slope, Venezuela, with special reference to Suborder Rotailiinaand its distribution. Caribbean Journal of Science, 7:95-133.

Sellier de Civrieux, J.M. 1968. Cuatro géneros nuevos de foraminíferos del Mar Caribe. Boletin Instituto Oceanografico Universidad de Oriente, 7:149-193. 
Sellier de Civrieux, J.M. 1977a. Foraminíferos indicadores de comunidades bentonicas recientes en Venezuela. Parte II: ecología y distribución de los foraminiferos más frecuentes de la plataforma continental en el Parque Nacional Mochima. Boletin Instituto Oceanografico Universidad de Oriente, 16:3-62.

Sellier de Civrieux, J.M. 1977b. Las Discorbidae del Mar Caribe frente a Venezuela. Cuadernos Oceanográficos Universidad de Oriente, 6:3-106.

Sellier de Civrieux, J.M. \& Ruíz, J.M. 1971. La influencia de los parametros fisico-quimicos del fondo en las facies de foraminiferos bentonicos. Boletin Instituto Oceanografico Universidad de Oriente, 10:15-34.

Tedesco, K.A. \& Thunell, R.C. 2003a. Seasonal and interannual variations in planktonic foraminiferal flux and assemblage composition in the Cariaco Basin, Venezuela. Journal of Foraminiferal Research, 33:192-210. doi:10.2113/33.3.192

Tedesco, K. \& Thunell, R. 2003b. High resolution tropical climate record for the last 6,000 years. Geophysical Research Letter, 30:1891. doi:10.1029/2003GL017959

Todd, R. \& Bronnimann, P. 1957. Recent Foraminifera and Thecamoebina from the Eastern Gulf of Paria, Trinidad. Cushman Foundation for Foraminiferal Research, Special Publications, 3:1-43.

van Andel, T.H. 1967. The Orinoco Delta. Journal of Sedimentary Research, 37:297-310. doi:10.1306/74d716c2-2b21-11d7$8648000102 c 1865 d$

van der Zwaan, G.J. \& Jorissen, F.J. 1991. Biofacial patterns in river-induced shelf anoxia. In: R.V. Tyson \& T.H. Pearson (eds.) Modern and Ancient Continental Shelf Anoxia, Geological Society of London, p. 65-82.

Wilson, B. 2000. Benthonic foraminifera as a tool in environmental quality control: two Caribbean examples. GSTT $2000 \mathrm{SPE}$ CONFERENCE AND EXHIBITION, 2000. Abstracts, Portof-Spain.
Wilson, B. 2008. Population structures among epiphytal foraminiferal communities, Nevis, West Indies. Journal of Micropalaeontology, 27:63-73. doi:10.1144/jm.27.1.63

Wilson, B. 2010. Effect of hurricanes on guilds of nearshore epiphytal foraminifera, Nevis, West Indies. Journal of Foraminiferal Research, 40:327-343. doi:10.2113/gsjfr.40.4.327

Wilson, B. \& Costelloe, A. 2011. Benthonic foraminiferal paleoecology of the Pleistocene in DSDP Hole 148, Aves Ridge, Eastern Caribbean Sea. Journal of Foraminiferal Research, 41:363-370. doi:10.2113/gsjfr.41.4.363

Wilson, B. \& Dave, R.A. 2006. Detecting seasonality using times series analysis: comparing foraminiferal population dynamics with rainfall data. Journal of Foraminiferal Research, 36:108115. doi:10.2113/36.2.108

Wilson, B. \& Hayek, L.C. 2015. Late Quaternary benthic foraminifera and the Orinoco Plume. Marine Micropaleontology, 121:85-96. doi:10.1016/j.marmicro.2015.11.004

Wilson, B. \& Hayek, L.C. 2017. Islands, currents, eddies, fronts . . . and benthic foraminifera: controls on neritic distributions off Trinidad. Micropaleontology, 63:15-26.

Wilson, B. \& Hayek, L.C. 2019. Planktonic foraminifera as indicators of oceanographic complexity on the southern Caribbean Sea continental shelf. Estuarine, Coastal and Shelf Science, 228:106359. doi:10.1016/j.ecss.2019.106359

Wilson, B.; Hayek, L.C. \& Ramdin, K.A. 2018. An eddy, a wake and a plume: controls on bathyal foraminifera around Tobago, western tropical Atlantic Ocean. PalZ, 92:561-575. doi:10.1007/ s12542-018-0402-z

WoRMS Editorial Board. 2019. World Register of Marine Species. Available at http://www.marinespecies.org; accessed on 09/17/2018.

Received in 03 September, 2019; accepted in 15 March, 2021. 
Appendix 1. Species of foraminifera of Chichiriviche de La Costa (Vargas, Venezuela) and their distribution between the four different depths. Abbreviations: $\mathbf{R}$, rare, less than five organisms by taxa/sample; F, few, between six to nine organisms by taxa/sample; C, common, between 10-20 organisms by taxa/sample; A, abundant, more than 21 organisms by taxa/sample.

\begin{tabular}{|c|c|c|c|c|c|}
\hline Species & & $10 \mathrm{~m}$ & $20 \mathrm{~m}$ & $30 \mathrm{~m}$ & $40 \mathrm{~m}$ \\
\hline Affinetrina quadrilateralis & (d’Orbigny, 1839) & $\mathrm{R}$ & & & \\
\hline Ammobaculites agglutinans & (d’Orbigny, 1846) & & & $\mathrm{R}$ & \\
\hline Ammoglobigerina globigeriniformis & (Parker \& Jones, 1865) & $\mathrm{F}$ & $\mathrm{F}$ & $\mathrm{R}$ & $\mathrm{F}$ \\
\hline Ammonia spp. & & & $\mathrm{R}$ & & \\
\hline Amphistegina lessonii & d'Orbigny in Guérin-Méneville, 1832 & $\mathrm{C}$ & A & A & $\mathrm{F}$ \\
\hline Articularia sagra & (d'Orbigny, 1839) & $\mathrm{R}$ & & & \\
\hline Articulina mucronata & (d’Orbigny, 1839) & & $\mathrm{R}$ & & \\
\hline Articulina multilocularis & Brady, Parker \& Jones, 1888 & $\mathrm{R}$ & & & \\
\hline Articulina pacifica & Cushman, 1944 & $\mathrm{~F}$ & $\mathrm{R}$ & & \\
\hline Baggina spp. & & & $\mathrm{R}$ & & \\
\hline Bigenerina nodosaria & d’Orbigny, 1826 & & & & $\mathrm{R}$ \\
\hline Bolivina spp. & & $\mathrm{R}$ & & $\mathrm{R}$ & $\mathrm{R}$ \\
\hline Borelis pulchra & (d’Orbigny, 1839) & $\mathrm{R}$ & & $\mathrm{R}$ & \\
\hline Borelis schlumbergeri & (Reichel, 1937) & $\mathrm{R}$ & & $\mathrm{R}$ & \\
\hline Bulimina spp. & & $\mathrm{R}$ & & & \\
\hline Buliminella elegantissima & (d'Orbigny, 1839) & $\mathrm{R}$ & & & \\
\hline Cancris spp. & & $\mathrm{R}$ & $\mathrm{R}$ & $\mathrm{R}$ & \\
\hline Candeina nitida & d’Orbigny, 1839 & & & & $\mathrm{R}$ \\
\hline Carterina spiculotesta & (Carter, 1877) & & & & $\mathrm{R}$ \\
\hline Cibicidoides pseudoungeriana & (Cushman, 1922) & & $\mathrm{R}$ & & $\mathrm{R}$ \\
\hline Cibicidoides spp. & & $\mathrm{R}$ & & & $\mathrm{R}$ \\
\hline Cornuspira involvens & (Reuss, 1850) & $\mathrm{R}$ & & & \\
\hline Cribroelphidium poeyanum & (d’Orbigny, 1839) & $\mathrm{R}$ & & & \\
\hline Cribroelphidium williamsoni & (Haynes, 1973) & $\mathrm{R}$ & & & \\
\hline Cymbaloporetta bradyi & (Cushman, 1915) & & $\mathrm{R}$ & & \\
\hline Cymbaloporetta plana & (Cushman, 1924) & $\mathrm{R}$ & & & \\
\hline Dentalina vertebralis & (Batsch, 1791) & & $\mathrm{R}$ & & $\mathrm{R}$ \\
\hline Discammina compressa & (Goës, 1882) & & & & $\mathrm{F}$ \\
\hline Discorbis mediterraneus & Risso, 1826 & & & $\mathrm{R}$ & \\
\hline Dorothia scabra & (Brady, 1884) & & $\mathrm{R}$ & & $\mathrm{R}$ \\
\hline Elphidium advenum & (Cushman, 1922) & & $\mathrm{R}$ & & \\
\hline Elphidium sagrum & (d'Orbigny, 1839) & $\mathrm{R}$ & $\mathrm{R}$ & $\mathrm{R}$ & \\
\hline Eponides repandus & (Fichtel \& Moll, 1798) & & $\mathrm{R}$ & $\mathrm{F}$ & $\mathrm{R}$ \\
\hline Flintinoides labiosa & (d’Orbigny, 1839) & & $\mathrm{R}$ & & $\mathrm{F}$ \\
\hline Fursenkoina spp. & & & & & $\mathrm{R}$ \\
\hline Gaudryina spp. & & & & $\mathrm{R}$ & \\
\hline Glabratella spp. & & $\mathrm{R}$ & $\mathrm{R}$ & $\mathrm{R}$ & \\
\hline Globigerina bulloides & d’Orbigny, 1826 & & $\mathrm{R}$ & & $\mathrm{R}$ \\
\hline Globigerina spp. & & $\mathrm{R}$ & & $\mathrm{R}$ & $\mathrm{R}$ \\
\hline Globigerinella siphonifera & (d’Orbigny, 1839) & & & & $\mathrm{R}$ \\
\hline Globigerinita glutinata & (Egger, 1893) & & & & $\mathrm{R}$ \\
\hline Globigerinoides conglobatus & (Brady, 1879) & & & $\mathrm{R}$ & \\
\hline Globigerinoides extremus & Bolli \& Bermúdez, 1965 & & $\mathrm{R}$ & & \\
\hline Globigerinoides ruber & (d’Orbigny, 1839) & $\mathrm{F}$ & $\mathrm{C}$ & A & A \\
\hline Globigerinoides spp. & & & & & $\mathrm{R}$ \\
\hline Globoconella inflata & (d’Orbigny, 1839) & & & & $\mathrm{R}$ \\
\hline Globorotalia menardii & (d'Orbigny in Parker, Jones \& Brady, 1865) & $\mathrm{R}$ & $\mathrm{F}$ & A & A \\
\hline
\end{tabular}


Appendix 1. Cont.

\begin{tabular}{|c|c|c|c|c|c|}
\hline Species & & $10 \mathrm{~m}$ & $20 \mathrm{~m}$ & $30 \mathrm{~m}$ & $40 \mathrm{~m}$ \\
\hline Gypsina vesicularis & (Parker \& Jones, 1860) & & & $\mathrm{R}$ & \\
\hline Hanzawaia concentrica & (Cushman, 1918) & & & $\mathrm{R}$ & \\
\hline Hastigerina pelagica & (d’Orbigny, 1839) & $\mathrm{R}$ & $\mathrm{R}$ & $\mathrm{R}$ & $\mathrm{C}$ \\
\hline Hauerina atlantica & (Cushman, 1946) & $\mathrm{F}$ & & & \\
\hline Hauerina pacifica & (Cushman, 1917) & $\mathrm{R}$ & & & \\
\hline Heterostegina depressa & (d’Orbigny, 1826) & & $\mathrm{R}$ & $\mathrm{R}$ & \\
\hline Quiqueloculina variolata & (d'Orbigny in Terquem, 1878) & $\mathrm{R}$ & & & \\
\hline Lachlachella spp. & & & & $\mathrm{R}$ & \\
\hline Laevipeneroplis bradyi & (Cushman, 1930) & $\mathrm{F}$ & & & \\
\hline Laevipeneroplis proteus & (d’Orbigny, 1839) & & $\mathrm{R}$ & $\mathrm{R}$ & \\
\hline Lenticulina spp. & & & $\mathrm{R}$ & & \\
\hline Marginulina spp. & & & & & $\mathrm{R}$ \\
\hline Martinotiella spp. & & $\mathrm{R}$ & & & \\
\hline Miliolinella subrotunda & (Montagu, 1803) & $\mathrm{R}$ & & & \\
\hline Miliolinella webbiana & (d'Orbigny, 1839) & $\mathrm{R}$ & & & $\mathrm{R}$ \\
\hline Milionella spp. & & $\mathrm{C}$ & $\mathrm{R}$ & $\mathrm{C}$ & $\mathrm{F}$ \\
\hline Neoeponides antillarum & (d'Orbigny, 1839) & $\mathrm{R}$ & & & \\
\hline Neogloboquadrina dutertrei & (d'Orbigny, 1839) & & $\mathrm{R}$ & $\mathrm{F}$ & $\mathrm{F}$ \\
\hline Miliolid unidentified & & & & & $\mathrm{R}$ \\
\hline Nodobaculariella cassis & (d’Orbigny, 1839) & & $\mathrm{R}$ & & \\
\hline Nonionella spp. & & $\mathrm{R}$ & & & \\
\hline Nonionoides spp. & & & & & $\mathrm{R}$ \\
\hline Orbulina universa & d'Orbigny, 1839 & & $\mathrm{R}$ & $\mathrm{F}$ & $\mathrm{C}$ \\
\hline Orectostomina camachoi & Seiglie, 1965 & & & & $\mathrm{R}$ \\
\hline Oridorsalis umbonatus & (Reuss, 1851) & & $\mathrm{R}$ & & \\
\hline Patellina spp. & & & & & $\mathrm{R}$ \\
\hline Planispirillina inaequalis & (Brady, 1879) & $\mathrm{R}$ & & & \\
\hline Planorbulina distoma & (Terquem, 1876) & $\mathrm{R}$ & $\mathrm{R}$ & & $\mathrm{F}$ \\
\hline Planulina foveolata & & & & & $\mathrm{R}$ \\
\hline Psammosphaera spp. & & & & & $\mathrm{R}$ \\
\hline Pseudohauerinella orientalis & (Cushman, 1946) & & $\mathrm{R}$ & & \\
\hline Pseudonodosinella elongata & (Grzybowski, 1898) & & & & $\mathrm{R}$ \\
\hline Pseudopyrgo spp. & & $\mathrm{R}$ & & & \\
\hline Pseudotriloculina spp. & & $\mathrm{R}$ & & & \\
\hline Pulleniatina finalis & Banner \& Blow, 1967 & & $\mathrm{R}$ & & $\mathrm{R}$ \\
\hline Pulleniatina obliculata & (Parker \& Jones, 1862) & & & $\mathrm{R}$ & \\
\hline Pulleniatina primalis & Banner \& Blow, 1967 & & & $\mathrm{R}$ & \\
\hline Pyrgo murrhina & (Schwager, 1866) & & $\mathrm{R}$ & & \\
\hline Pyrgo subsphaerica & (d’Orbigny, 1839) & $\mathrm{R}$ & $\mathrm{R}$ & $\mathrm{R}$ & $\mathrm{R}$ \\
\hline Pyrgo williamsoni & (Silvestri, 1923) & $\mathrm{R}$ & $\mathrm{R}$ & $\mathrm{R}$ & $\mathrm{R}$ \\
\hline Quinqueloculina agglutinans & (d’Orbigny, 1839 ) & & & $\mathrm{R}$ & \\
\hline Quinqueloculina bradyana & Cushman, 1917 & & $\mathrm{R}$ & & \\
\hline Quiqueloculina carinata & (d’Orbigny, 1850) $\dagger$ & $\mathrm{R}$ & & & \\
\hline Quinqueloculina laevigata & Deshayes, 1831 & A & $\mathrm{R}$ & & \\
\hline Quinqueloculina lata & (Terquem, 1876) & & & & $\mathrm{R}$ \\
\hline Quinqueloculina parkeri & (Brady, 1881) & $\mathrm{R}$ & $\mathrm{R}$ & & \\
\hline Quinqueloculina poeyana & (d'Orbigny, 1839) & $\mathrm{R}$ & & & \\
\hline
\end{tabular}


Appendix 1. Cont.

\begin{tabular}{|c|c|c|c|c|c|}
\hline Species & & $10 \mathrm{~m}$ & $20 \mathrm{~m}$ & $30 \mathrm{~m}$ & $40 \mathrm{~m}$ \\
\hline Quinqueloculina polygona & (d'Orbigny, 1839) & $\mathrm{F}$ & $\mathrm{R}$ & $\mathrm{R}$ & \\
\hline Quinqueloculina seminula & (Linnaeus, 1758) & $\mathrm{R}$ & & & \\
\hline Quinqueloculina sierralta & (McCulloch, 1977 ) & $\mathrm{R}$ & & & \\
\hline Quinqueloculina variolata & d'Orbigny in Terquem, 1878 & $\mathrm{R}$ & & & \\
\hline Quinqueloculina spp. & & A & $\mathrm{R}$ & $\mathrm{R}$ & $\mathrm{R}$ \\
\hline Reophax fusiformis & (Williamson, 1858) & & & & $\mathrm{R}$ \\
\hline Reophax scorpiurus & Montfort, 1808 & & & & $\mathrm{R}$ \\
\hline Rosalina floridana & (Cushman, 1922) & $\mathrm{F}$ & & & \\
\hline Rosalina neapolitana & (Hofker, 1951) & $\mathrm{R}$ & & & \\
\hline Rotorbinella rosea & (d’Orbigny in Guérin-Méneville, 1832) & $\mathrm{F}$ & $\mathrm{R}$ & & \\
\hline Sahulia barkeri & (Hofker, 1978) & $\mathrm{R}$ & & & \\
\hline Sigmoilopsis arenata & (Cushman, 1921) & & $\mathrm{R}$ & & \\
\hline Sigmoilopsis schlumbergeri & (Silvestri, 1904) & & & & $\mathrm{R}$ \\
\hline Siphonaperta spp. & & $\mathrm{R}$ & & & \\
\hline Siphonina tubulosa & Cushman, 1924 & $\mathrm{R}$ & $\mathrm{F}$ & $\mathrm{F}$ & $\mathrm{R}$ \\
\hline Sorites marginalis & (Lamarck, 1816) & & $\mathrm{R}$ & & \\
\hline Sorites orbiculus & (Forsskål in Niebuhr, 1775) & $\mathrm{R}$ & $\mathrm{R}$ & & \\
\hline Sphaerogypsina globulus & (Reuss, 1848) & & $\mathrm{R}$ & & \\
\hline Sphaerogypsina spp. & & & & $\mathrm{R}$ & $\mathrm{R}$ \\
\hline Spirilina vivipara & (Ehrenberg, 1843) & $\mathrm{F}$ & $\mathrm{R}$ & & $\mathrm{R}$ \\
\hline Spirilina spp. & & $\mathrm{R}$ & & & \\
\hline Spiroloculina angulata & (Cushman, 1917) & $\mathrm{R}$ & & & \\
\hline Spiroloculina antillarum & d'Orbigny, 1839 & $\mathrm{R}$ & $\mathrm{R}$ & $\mathrm{R}$ & \\
\hline Spiroloculina communis & Cushman \& Todd, 1944 & & $\mathrm{R}$ & & $\mathrm{R}$ \\
\hline Spiroloculina convexa & Said, 1949 & $\mathrm{R}$ & & $\mathrm{R}$ & \\
\hline Spiroloculina spp. & & & & $\mathrm{R}$ & $\mathrm{R}$ \\
\hline Spirorutilus carinatus & (d’Orbigny, 1846) & & & & $\mathrm{R}$ \\
\hline Spirosigmoilina bradyi & (Collins, 1958) & $\mathrm{R}$ & & & \\
\hline Subreophax aduncus & (Brady, 1882) & & $\mathrm{R}$ & & \\
\hline Textularia agglutinans & d'Orbigny, 1839 & $\mathrm{~F}$ & $\mathrm{~F}$ & $\mathrm{C}$ & $\mathrm{F}$ \\
\hline Textularia candeiana & d'Orbigny, 1839 & $\mathrm{R}$ & & & $\mathrm{R}$ \\
\hline Textularia gramen & d'Orbigny, 1846 & & & $\mathrm{R}$ & \\
\hline Textularia porrecta & Brady, 1884 & $\mathrm{~F}$ & & & \\
\hline Trifarina spp. & & & & $\mathrm{R}$ & \\
\hline Trilobatus immaturus & (LeRoy, 1939) & & & $\mathrm{C}$ & $\mathrm{F}$ \\
\hline Trilobatus sacculifer & (Brady, 1877) & & $\mathrm{R}$ & $\mathrm{R}$ & \\
\hline Trilobatus trilobus & (Reuss, 1850) & & $\mathrm{R}$ & $\mathrm{R}$ & $\mathrm{F}$ \\
\hline Trilobatus spp. & & & & $\mathrm{R}$ & \\
\hline Triloculina oblonga & (Montagu, 1803) & & $\mathrm{R}$ & & \\
\hline Triloculina tricarinata & d'Orbigny in Deshayes, 1832 & & $\mathrm{R}$ & $\mathrm{F}$ & \\
\hline Triloculina trigonula & (Lamarck, 1804) & $\mathrm{R}$ & & & $\mathrm{R}$ \\
\hline Triloculina spp. & & $\mathrm{R}$ & & & $\mathrm{R}$ \\
\hline Wiesnerella auriculata & (Egger, 1893) & $\mathrm{R}$ & $\mathrm{R}$ & & \\
\hline
\end{tabular}

